THE RESEARCH INSTITUTE OF INDUSTRIAL ECONOMICS

WORKING PAPER No. 491, 1997

NEW KEYNESIANISM AND AGGREGATE ECONOMIC ACTIVITY

BY ASSAR LINDBECK 
Assar Lindbeck:

\section{New Keynesianism and Aggregate Economic Activity ${ }^{1}$}

The basic analytical message of traditional Keynesianism was probably: (i) that a market economy, contradicting a strictly interpreted Say's law, may run into a situation of prolonged aggregate excess supply of labour -- what Keynes himself called "unemployment equilibrium"; and (ii) that aggregate product-demand shocks are important explanations of observed macroeconomic fluctuations, including changes in unemployment. Traditional Keynesians were also quite optimistic about the possibilities of counteracting such shocks by demand management policy and of moving the national economy out of situations of prolonged unemployment by such policy actions.

This paper addresses various attempts by so-called new Keynesians, writing mainly in the 1980s and 1990s, to strengthen the analytical basis, in particular the microeconomic foundations, of these assertions. What, exactly, have then the new Keynesians accomplished, and how should their contributions be valued in the relation to other recent contributions to macroeconomics? The most characteristic ambitions of the new Keynesians have probably been to explain why real wages are rigid and hence do not always clear the labour market, and why nominal prices and wages are sticky, with the consequence that aggregate product-demand shocks systematically affect aggregate output, employment and unemployment. New Keynesians have also emphasised that this type of behaviour is fully consistent with notions of "rationally" optimising private agents. Some new Keynesians have also stressed the importance of the financial structure of firms, and of quantity rationing in financial markets, for aggregate output and employment.

\footnotetext{
'I am grateful for comments on a previous version of the paper from Robert Solow, Lars E. O. Svensson and seminar participants at the Institute for International Economic Studies, Stockholm University. Julie Sundquist has improved the language.
} 


\section{Existence and persistence of unemployment}

A well-known weakness of traditional Keynesian models, including The General Theory, was the absence of convincing microeconomic foundations for the asserted non-clearance of the labour market. More specifically, these models did not explain why unemployed workers are often unable to get jobs by underbidding existing real wages of employed workers. This gap in Keynesian economics has recently been filled to a considerable extent. Today there are reasonable micro-based explanations of why the labour market may not clear, and hence why aggregate excess supply of labour may arise. It is useful to classify these explanations into two categories. The first category emphasises government-created distortions in the economic system, in particular in the labour market. This approach, which may be more relevant for Western Europe than for the United States, has been pursued not only by a number of economists, economic journalists and politicians, but also by international organisations such as the IMF, the OECD and the EC. Obvious examples of such distortions are high minimum wages, wide marginal tax wedges, regulations and benefit systems that boost the market powers of incumbent workers and labour unions, as well as various government-created obstacles to the entry and expansion of firms. Classical, i.e., pre-Keynesian, economists would not have had much difficulty siding with this type of explanation of unemployment.

New Keynesians have chosen a different track. They refer mainly to "spontaneous" market imperfections -- what some of them call "market imperfections on a grand scale" (quote from Mankiw and Romer, 1991, p.1). In particular, new Keynesians usually advocate recent theories of non-clearing wage formation, especially the efficiency wage theory. To some extent, they also adhere to the insideroutsider theory, which is easy to combine with union-monopoly models, unionbargaining models and considerations to government regulations such as job-security legislation. One reason why new Keynesians have relied more on the efficiency-wage theory than on the insider-outsider theory is perhaps that they are more inspired by conditions in the United States than in Western Europe, where insiders have stronger market powers. Theories of implicit contracts and job search also feature in labourmarket analyses by new Keynesians, as in modern labour-market analysis in general. 
However, these theories do directly address the issue of involuntary unemployment, i.e., they do not explain why unemployed workers are, for long periods, unable to get jobs on the same conditions as, or even at lower wages than actually employed workers with the same ability.

Aggregate versions of efficiency-wage, insider-outsider and union theories of wage formation usually imply that real wages, aggregate employment and unemployment are determined simultaneously at the intersection of a downward sloping aggregate labour demand function with an upward sloping wage-setting function rather than an aggregate labour supply function. The pioneering works using this approach are probably Shapiro and Stiglitz (1984) and Layard and Nickell (1986). An obvious merit of this approach is that it determines aggregate unemployment and not just aggregate employment. Another advantage is that large fluctuations in aggregate employment can be explained without the counterfactual assumption of highly elastic labour supply in response to actual or expected changes in real wage rates, as workers are generally not on their labour supply functions in this type of model. Moreover, as firms are assumed to operate under imperfect competition in the product market, prices are set by explicitly specified agents; no mythical auctioneer has to be imposed. On all these accounts, this approach to employment determination is superior to new classical macroeconomics and real business cycle models. What is still lacking is a convincingly performed integration of this type of analysis -- dealing with wage setting, stock demand and stock supply of labour -- with search theory, emphasising flows into and out of unemployment.

Though most new-Keynesian economists seem to accept some concept of "equilibrium unemployment", they often rely on NAIRU formulations, in terms of rates of change in nominal wages, rather than on the static approach referred to above in terms of the level of real wages. An obvious difference between the two concepts is, of course, that the NAIRU is derived from an expectations-augmented Phillips curve rather than from a static analysis of the interaction between labour demand and real wage-setting behaviour. A related, and more substantive, difference is that the NAIRU is defined as a situation where the rate of (wage or price) inflation is constant, whereas the only requirement of the concept of equilibrium unemployment discussed above is that real wages are constant (when there is no productivity growth); the rate 
of change in nominal variables may rise, fall or be constant. The two approaches may be reconciled, however, by grafting nominal wage and price dynamics onto the static approach (Lindbeck, 1993, Appendix B).

These various concepts of unemployment equilibrium are, however, entangled in well-known theoretical and empirical complications. ${ }^{2}$ One is the difficulty of distinguishing it from "unemployment persistence", i.e., the slow pace at which the actual unemployment rate falls after unemployment-generating shocks. Indeed, statistically calculated equilibrium rates tend to shadow actual rates. Moreover, our knowledge about the determinants of both the equilibrium unemployment rate and the degree of unemployment persistence is quite modest.

In the extreme case where unemployment persistence turns into "full hysteresis", and hence the expected future unemployment rate is equal to the actual rate, there is in fact an infinite number of equilibria; the equilibrium unemployment rate becomes a random walk. When new Keynesians have discussed the possibility of multiple equilibria, however, they have usually been concerned with other mechanisms. ${ }^{3}$ Examples are multiple equilibria in the context of small costs ("menu costs") of changing prices, with different equilibria depending on whether firms change their prices or not (Stiglitz, 1979; Rotemberg, 1987, pp. 80-82); search externalities, with low or high activity equilibria depending on the different "thickness" of markets in booms and recessions (Diamond, 1982 ); technological complementarities in the production by different firms (Bryant, 1983); and increasing returns, which are easier to exploit when aggregate economic activity is high than when it is low (Schleifer, 1986).

In all these cases, even temporary shocks -- i.e., shocks that are subsequently reversed -- may (permanently) shift the economy from one equilibrium to another. Examples are monetary shocks and real demand shocks that are reversed after some time. However, the concept of multiple equilibria that best fits into the Keynesian tradition is probably bootstrap (or sunspot) equilibria, connected with unexplained (or even unexplainable) optimism or pessimism among economic agents concerning, e.g.,

\footnotetext{
${ }^{2}$ As "unemployment equilibrium" implies excess supply of labor, it would perhaps be better to talk about a "quasi-equilibrium rate of unemployment", QERU; see Lindbeck (1993).

${ }^{3}$ For a survey, see Rotemberg (1987), and for a general discussion, Cooper and John (1988), who highlight spillover effects and strategic complementarites in connection with multiple equilibria.
} 
income, sales, prices or profits (Woodford, 1986). Though shifts in optimism and pessimism have always played some role in theories of business cycles (Haberler, 1941, pp. 142-150), macroeconomic bootstrap equilibria recall, in particular, Keynes' metaphor of "animal spirit" among investors in physical assets and "beauty contests" in markets of financial assets. Among the new Keynesians, such themes have recently been discussed under headings such as self-fulfilling rational-expectations equilibria and macroeconomic coordination failures, which may make the national economy settle at a low-activity, suboptimal equilibrium (Cooper and John, 1988).

It is rather unclear how useful macroeconomic models with multiple equilibria will turn out to be. The policy implications are certainly much more obscure than in the textbook Keynesian IS-LM model, not to speak of "the Keynesian cross" of income determination. Indeed, the asserted uniqueness and predictability of macroeconomic equilibrium were important features of traditional Keynesianism, distinguishing it from alternative macroeconomic theories, such as those developed by Hayek and the Stockholm School. Should this type of model turn out to be the most realistic way of representing macroeconomic relations in the real world, it will be extremely difficult, if not impossible, to predict the effects of policy actions with sufficient accuracy to defend activist stabilisation policy.

Aggregate representations of the labour market are, of course, only a "first rough shot" at the employment issue. To some extent, both the efficiency-wage theory and the insider-outsider theory help explain relative wages and the distribution of unemployment among different categories of workers. Search models also provide a promising method to analyse the "fine structure" of the labour market. A realistic analysis of relative wages and the distribution of unemployment should, however, also include analyses of the effects of government interventions in the labour market, in particular in Europe.

Disaggregation of the labour market also highlights serious difficulties with the concept of "involuntary unemployment" as it is often possible for an unemployed worker to get some kind of job in the informal labour market, where wages may be regarded as market-clearing. Obvious examples include taxi drivers, restaurant and cleaning personnel, self-employed flower salesmen on street corners, etc. Still, an unemployed worker is discriminated against if he is unable to get a job in the formal 
labour market, in spite of the fact that his reservation wage may be lower than the actual wage received by incumbent workers with the same ability. The "involuntariness" then consists of arbitrarily facing a more restricted choice set than others with similar ability because of social, i.e., man-made, constraints. This restriction is particularly strong in countries where the informal labour market is very thin either because of extensive and strict enforcement of minimum wages and other regulations, or because of wide-ranging collective bargaining agreements between unions and employers' associations. Indeed, this is the case in several countries in Western Europe.

\section{The transmission of aggregate product-demand shocks}

It is hardly easier to explain the transmission of aggregate product-demand shocks to the labour market than to clarify the existence and persistence of (involuntary) unemployment. Such analytical difficulties are unavoidable in models where all behaviour functions are homogeneous in degree zero in absolute prices and nominal money balances (the absence of money illusion), and where nominal prices and wages are fully flexible. Not only does the classical dichotomy between real and nominal variables hold in such models. The labour market is, in fact, a self-contained subset in the sense that the level of aggregate product demand does not enter into the behaviour functions in the labour market, and hence does not directly influence aggregate employment.

These considerations are relevant not only for models with clearing labour markets, but also for models with rigid real wages and excess supply of labour. The reason is, of course, that the conventional (notional) labour-demand function is derived from the standard marginal condition for profit-maximising firms, which means that the labour-demand function simply reflects properties of the production function. Indeed, the development of macroeconomic theory in recent decades may to a considerable extent be seen as a long and cumbersome attempt to escape the "tyranny" of the downward sloping labour-demand curve and hence also to overcome the classical dichotomy. 
In the simple case of $s$ identical firms producing under imperfect competition, the labour-demand function (which in this case is a quasi-reduced function) may be written:

$$
N_{d}=s \cdot n+N_{g}=s \cdot f^{-1}[w /(1-m)]+N_{g}
$$

where $n$ is labour input and $f(n)$ the production function of an individual firm when the capital stock is given, $w$ the (real) product wage and $m$ Lerner's measure of "monopoly power" in the product market, where $m=1 / \eta ; \quad \eta$ then denotes the firmspecific elasticity of product demand. $N_{g}$ is government labour demand. The only ways in which, say, a positive product-demand shock may influence aggregate labour demand in the short run are then either via a fall in the real wage (when $\mathrm{f}^{\prime \prime}<0$ ) and a related movement along the labour-demand curve, or via a rightward shift of the aggregate labour-demand curve (in employment/real wage space). In the context of equation (1), the latter may take place in three alternative ways: via an induced rise in the elasticity of firm-specific product demand $(\eta)$; a rise in the marginal product of labour $\left(f^{\prime}\right)$; or an increase in the number of firms $(s)$. In a medium- and long-term perspective, labour demand may, of course, also be influenced via capital accumulation.

New Keynesians who have tried to identify transmission mechanisms as shifts in the labour-demand curve have often hypothesised that a rise in the level of aggregate product demand is systematically related to an increase in the firm-specific elasticity of product demand $(\eta)$, with a related reduction in the mark-up of prices on marginal costs; for surveys see Stiglitz (1984) and Rotemberg (1987). The asserted reason is either a rise in the elasticity of aggregate product demand or stiffer competition between firms when aggregate demand or output prices increase. ${ }^{4}$ It is an open question, however, whether this transmission mechanism is systematic and strong enough to support a reliable transmission mechanism. For instance, changes in $\eta$ for a representative firm depend not only on variations in the degree of competition between firms but also on changes in the composition of product demand with respect to products and individuals with different price elasticities.

\footnotetext{
${ }^{4}$ The mark-up may be written $\mathrm{p} / \mathrm{c}=1 /(1-1 / \eta)$, where $p$ is the product price and $c$ the marginal cost.
} 
Transmissions from product demand to labour demand via the second mechanism, i.e., via $f^{\prime}$, may occur when increased spending takes the form of higher investment in infrastructure by the government, as the marginal products of both labour and capital would then be expected to increase in private firms. From that point of view, the high level of infrastructure investment in OECD countries in the 1950s and 1960s probably contributed to some rightward shifts of the aggregate labourdemand curve. The strength of the third channel, i.e., the entry of firms (or plants) in connection with higher aggregate product demand, depends on the ease of such entry, which highlights the role of various obstacles to entrepreneurship, including those created by the government -- certainly not an issue that has engrossed Keynesians, whether old or new. An increase in direct government demand for labour $\left(N_{d}\right)$, including public works programmes, can also, of course, shift the aggregate demand curve for labour to the right, although at least some private labour demand is then likely to be crowded out -- via substitutions between private and government labour demand, higher taxes or interest rates in connection with the financing of increased government spending, tendencies for product wages to rise, etc.

There is an additional, though rather special, case where positive (negative) aggregate product-demand shocks will result in increased (reduced) output and employment at unchanged real wage rates, namely when both the elasticity of product demand and the marginal costs of labour are constant $\left(f^{\prime \prime}=0\right){ }^{5}$ In this special case, aggregate product-demand shocks will increase aggregate employment without changes in real wages and without relying on shifts in the labour-demand curve. Some models presented by new Keynesians depend on this mechanism (Hart, 1982; Hall, 1986).

Difficulties in explaining the transmission of aggregate product-demand shocks to the labour market, and hence in overcoming the classical dichotomy in the context of fully flexible nominal prices and wages are, of course, the background for the new Keynesians' emphasis on nominal rigidities. Barro and Grossman (1971) were probably the first to construct a complete fixed-price macroeconomic model combining sales-constrained demand for labour, due to rigid nominal prices, with

\footnotetext{
${ }^{5}$ This is seen from the formula in the preceeding footnote: when $\eta$ and $c$ are constant, $p$ is also constant.
} 
income-constrained demand for consumer goods due to rigid nominal wages -resulting in mutual spillovers between product demand and labour demand, and related output multipliers. This model, however, implied a rather curious market form by assuming that firms were unable to sell as much as they would like, in spite of the fact that perfect competition was assumed in the product market. This explains why new Keynesians have instead assumed imperfect competition. That has made it easier both to explain nominal rigidities and to show that individual firms' decisions not to adjust prices immediately induce them to adjust sales and output to shifts in demand. This also creates demand externalities for other firms and markets. As in the BarroGrossman model, positive (negative) product-demand shocks induce labour demand to wind up to the right (left) of the notional labour-demand curve, and households' consumption above (below) the notional consumption function. ${ }^{6}$

It is far from clear today which of the many explanations of price rigidity suggested by new Keynesians make the most sense. Attempted explanations include concern for goodwill (implicit contacts), cost-based pricing rules and imperfect information about the effects of price changes (for instance because of uncertainty about the reactions of competitors); see Blinder (1994) for a survey and an empirical study. However, the favourite recourse among new Keynesians has no doubt been to refer to "menu costs". Such theories may very well help explain why firms often use non-pricing methods to allocate sales, such as variations in backlogs and delivery times (Carlton, 1986). They may also highlight why firms react to product-demand shocks by variations in their utilisation of the existing workforce within the firm (i.e., variations in labour hoarding), and related changes in output. However, menu costs hardly explain why individual firms choose to change employment rather than prices in response to shifts in product demand. ${ }^{7}$ The costs of changing employment are probably much larger than the costs of changing prices, as evidenced, for instance, by

\footnotetext{
${ }^{6}$ It is well-known that higher wages have ambiguous short-run effects on economic activity and labour demand in this type of model with predetermined output prices. While higher wages induce some lowprofit firms to reduce output and employment, other firms react in the opposite way provided the marginal propensity to spend is higher for labour income than for profits and capital income.

${ }^{7}$ There is also some logical tension in the menu-cost argument. It is argued that the return to a firm from changing the output price is small because the profit function is flat (in profit/output price space) at maximum profit. But if the firm tends not to adjust its price to shifts in product demand, then the firm is not likely to be at maximum profit when new product-demand shocks occur. Moreover, small price changes occur quite often in the real world, which sheds some additional doubt on the menu-cost argument (Carlton, 1986).
} 
the hiring and firing costs of labour, which are particularly high in several countries in Europe.

A celebrated alternative, or rather complementary, way of explaning why aggregate product prices are sluggish is to rely on the absence of full synchronisation of price changes of individual firms. It turns out, however, that such staggering does not necessarily contribute to aggregate price inertia (Caplin and Spulber, 1987; Chari, Kehoe and McGrattan, 1996). The issue hinges crucially on the distribution of prices among firms relative to profit-maximum prices. Slow penetration of cost impulses among firms via changes in the prices of intermediate products in the context of a complex input-output system is perhaps a more important mechanism (Blanchard, 1983; Basu, 1995); this mechanism is accentuated by the existence of production lags between inputs and outputs in individual firms (Lindbeck and Snower, 1992). It has also been shown that rigidities of relative prices (and wages) tend to accentuate nominal rigidities in individual firms (Blanchard, 1983; Ball and Romer, 1990) -- a point that is valid regardless of the reasons for sluggish nominal prices and wages. ${ }^{8}$

The weaknesses of proposed explanations for sluggish prices should, of course, be compared to the flaws in alternative theories of transmission mechanisms from aggregate product demand to aggregate output and employment. For instance, Keynes' hypothesis in The General Theory that nominal wages are more sticky than nominal prices, and hence that positive (negative) product-demand shocks result in a fall (rise) in real wages, has not turned out to be based on solid empirical foundations. Indeed, this is one reason why new Keynesians, by contrast to Keynes himself, have chosen to emphasise stickiness of nominal product prices rather than nominal wages. Deficiencies in the realism of attemted explanations of sticky prices should also be compared with the limited realism of the assumption in new classical macroeconomics (following Friedman and Lucas) that private agents systematically confuse inflation and idiosyncratic changes in their own relative output prices. This is certainly a rather arbitrary, not to say farfetched assertion, as aggregate price indices are easily available. Limited realism of the explanations of sticky nominal prices should further be compared with the lack of realism of various assumptions found in

\footnotetext{
${ }^{8}$ The existence of a countercyclical firm-specific elasticity of product demand would also help explain sticky prices (Kimball, 1996).
} 
real business cycle models, e.g. regarding (exogenous) cyclical shifts in the aggregate production function, generated by (a more or less liberally interpreted) technology shifts, up and down.

In comparison with these alternative theories, the assumption of a slow response of nominal aggregate prices and wages to aggregate product-demand shocks looks rather innocuous. Indeed, the realism of assuming sluggish aggregate prices can hardly be questioned; aggregate prices do not usually jump in proportion to shifts in aggregate product demand or money supply. ${ }^{9}$ In addition, it is not unreasonable to base macroeconomic models on the assumption of a sluggish response of aggregate nominal prices and wages to aggregate demand shocks even if we do not (yet) understand the observed sluggishness very well -- a point that has been emphasised, e.g., by Malinvaud (1984).

An analysis tied to equation (1) -- with or without flexibility of nominal prices and wages -- is much too limited, however. For instance, transmissions via various financial factors are not included. In two-period (or multi-period) models, real interest rates enter not only the product-supply function and the investment function but also the labour-demand function; see, for instance, Henderson and Quandt (1971, pp. 310326); Mas-Colell et al. (1995, chap. 20). But if we want to understand why positive product-demand shocks would stimulate production and the demand for labour, this observation is not of much help, as real interest rates are likely to rise rather than fall in response to positive real aggregate product-demand shocks initiated by higher private or government propensities to spend. ${ }^{10}$ Such a multi-period approach reminds us, however, of the fact that, when nominal product prices are sluggish, expansionary monetary policies are likely to stimulate output and labour demand, for a while, via lower real interest rates.

\footnotetext{
${ }^{9}$ An important limitation in the analysis of transmission mechanisms by new Keynesians is their concentration on nominal shocks, in fact, usually exogenous changes in cash transfers ("helicopter money"). This is, of course, an unnecessary analytical constraint, which hardly does the "Keynesian approach" justice. After all, both Keynes himself and traditional Keynesians emphasised shifts in real aggregate demand, rather than monetary shocks, for instance due to changes in the propensity to invest or consume in the private sector or changes in government purchases of goods and services. The consequences of real demand shocks for output and unemployment are less easily eliminated by nominal price and wage increases than are the effects of money shocks.

${ }^{10}$ Though higher real interest rates induce substitution of labor for capital, there is a negative scale effect reducing the demand for both capital and labor.
} 
It is a commonplace today that interest-rate effects may be accentuated both by limitations on the supply side of the credit market and by certain features of the financial structure of firms. Indeed, such aspects had already been strongly, though informally, emphasised in the 1950s by economists connected with the Federal Reserve in New York, in particular Rosa (1951) -- the so-called "new theory of credit control". Similar discussions were pursued by the Radcliff Committee on monetary policy in the United Kingdom (Committee on the Working of the Monetary System, 1959). "' Somewhat surprisingly, these contributions seem to have been largely neglected when new Keynesians have returned to these issues.

Credit availability effects, i.e., the exercise of credit standards (such as requirements on collateral) and credit rationing by lenders, imply that potential borrowers are often not able to get all the credit they want at prevailing, or even higher, interest rates. Such exercise of credit standards and credit rationing may be modelled in terms of lenders' attitudes towards risk: there may be no interest rate high enough to compensate the lender for the risk associated with loan to a given borrower. The risk content of a loan (principal plus interest rate) may, in fact, rise so rapidly with the size of the offered interest rate that no interest rate can compensate the lender for the ensuing risk. Indeed, if a lender is doubtful about the ability of a loan applicant to repay the principal, he also has good reasons to doubt the ability of the applicant to pay the promised interest on the loan (Lindbeck, 1963, pp. 88-98, 236-245). Even the expected value of the repayment may fall when an applicant promises to pay a higher interest rate -- in today's terminology due to adverse selection and moral hazard. Such considerations have recently been emphasised and further clarified by some economists who are often classified as "new Keynesians", such as Stiglitz and Weiss (1981), Stiglitz (1992) and Bernanke and Gertler (1995).

It is misleading, of course, to treat credit-availability effects as an issue completely distinct from interest rates. If an applicant is refused a loan from one lender, he may turn to another, provided he is willing to pay the interest rates required by the latter, which means that it is important to analyse credit availability and interest rates simultaneously. As higher average interest rates are usually correlated with

\footnotetext{
"Rosa's contribution is discussed in Lindbeck (1962) and the Radcliff Report in Lindbeck (1963, pp. 234-252).
} 
stiffer credit standards and stricter credit rationing, concern for credit availability effects may be broadly reflected in an aggregate interest-rate variable. But it is doubtful whether these phenomena in the credit market, which reflect genuine uncertainty, should be regarded as expressions of "market failures", as asserted by some new Keynesians, i.e., Mankiw and Romer (1991).

There may also be potentially important transmission mechanisms connected with the financial structure of firms. In particular, production, labour demand and investment may be influenced via the availability of internal funds. For instance, firms may be "debt averse", both because debt incurs a fixed cost that raises the risk of winding up with liquidity problems or bankruptcy, and because debt tends to reduce the autonomy of the firm; early empirical studies along these lines are Butters and Lintner (1945) and Meyer and Kuh (1957). One way of formalising this issue is to assume that firms are interested not only in profits but also in the composition of their balance sheet. Formally, we may therefore assume that the firm maximises a preference function with profits, debt and various liquid assets as arguments. This means that the imputed cost of internal funds is lower than the costs of external funds, so that capital costs are kept down by high sales revenues (resulting in smaller debt) during boom periods. This provides a direct transmission mechanism from aggregate product demand to aggregate output and employment (Lindbeck, 1963, pp. 71-95). Denoting real interest rates by $r$, the real value of the holdings of financial assets by $a$ and the real value of debt by $d$, concern among firms for financial factors like these transform equation (1) into

$$
N_{d}=s \cdot n+N_{g}=s \cdot f^{1-1}[w /(1-m), r, a, d]+N_{g}
$$

The willingness of a firm to produce, purchase labour services and invest will then be affected not only by changes in explicit interest rates but also by changes in cash flows, for instance via changes in sales revenues and interest payments, as well as by changes in the prices of financial assets held by the firm. This means that both shifts in aggregate product demand and changes in monetary policy will directly influence production, investment and labour demand even when nominal prices and wages are fully flexible; this is what equation (2) tells us.

Transmission mechanisms associated the availability of credit (reflecting ability to borrow) and internal funds (reflecting willingness to borrow) have not been 
a central aspect in the analyses of most new Keynesians, but some economists who call themselves new Keynesians have certainly pursued this approach. Indeed, as quantities, and not just relative prices (interest rates) in financial markets are assumed to influence economic behaviour in this framework, such considerations fit, in principle, rather well into a Keynesian-type view of the world.

"Debt deflation" à la Irwin Fisher is a related phenomenon that has recently become a widely considered transmission mechanism via financial channels. One explanation of such effects is that credit contracts are often made in nominal terms and for a considerable period of time -- circumstances that still largely remain to be explained. Another reason is that nominal interest rates can hardly fall below zero (the nominal interest rate on money balances). For firms with more debt than financial claims, deflation may then have negative effects on production, investment and labour demand, which is consistent with equation (2). In The General Theory, of course, Keynes added that a process of falling aggregate nominal prices and wages may create expectations of a further fall in product prices, and hence a further increase in (expected) real interest rates, as well as redistributions of wealth and liquidity from debtors to creditors -- in the case of households as well as firms. The conclusion is that highly flexible prices and price expectations may in fact make aggregate output more sensitive to product demand shocks than in the case of sluggish prices. This observation, however, has been emphasised more by some traditional Keynesians, such as Tobin (1993), than by new Keynesians. After all, new Keynesians have tied macroeconomic instability to sluggish rather than to flexible prices.

\section{In conclusion}

The main contribution of the new Keynesians has perhaps been to strengthen the microeconomic foundations for the existence and persistence of aggregate excess supply of labour, and for various transmission mechanisms of aggregate productdemand shocks to output and employment. It is a commonplace, however, that many important contributions to macroeconomics during the last few decades have also been made by economists representing other traditions. Obvious, and highly celebrated, examples are the role of expectations about future government policies, as reflected in the rational expectations revolution and the analysis of time consistency 
and credibility problems and, more generally, various attempts to model politicians as endogenous variables. Although many new Keynesians seem to have accepted both the usefulness of rational expectations as a benchmark for their analysis, and the importance of credibility issues, it is fair to say that concerns about these issues have not been central to the economic policy analysis by new Keynesians. In other words, new Keynesians have not given much consideration to complications inherent in the dynamics of expectations concerning future government policies.

As in the case of traditional Keynesians, there has also been a general neglect of the supply side by new Keynesians, except mainly for their interest in price and wage setting and "spontaneous" market distortions. For instance, new Keynesians have not been at the forefront in arguing that the macroeconomic problems in Europe during that last two decades, including high and persistent unemployment, are related to market distortions created by governments. By a slight caricature, we may say that both traditional Keynesians and new Keynesians have tended to turn Say's law upside down by assuming, in fact, that demand creates its own supply -- regardless of how the supply side (including the labour market) functions. Moreover, by contrast to economists working with real business cycle models, new Keynesians have not devoted much effort to comparing the predictions of their overall models with empirical macroeconomic data, although partial-equilibrium econometric studies, for instance on price and wage setting behaviour and labour demand, do of course exist.

What, then, do recent developments in macroeconomics, by new keynesians as well as by others, mean for the possibilities of pursuing macroeonomic policy, including aggregate demand management? It is by now a rather generally accepted view that the possibilities are rather limited of conducting successful "fine tuning" of aggregate demand in the product market. Some new Keynesians probably share this scepticism. Aggregate demand management is more promising in situations of either very deep recessions or strongly overheated booms, as complications due to time lags, difficulties of forecasting and party-politics then play a more modest role. In this sense, "coarse-tuning" is more promising than fine-tuning. But if such a policy strategy is pursued, various persistence mechanisms may already have created either serious long-term unemployment or ingrained inflationary expectations, which limit the possibilities of reversing these trends fast by the help of aggregate demand 
management. This does not necessarily mean that discretionary stabilisation policy is a hopeless task. But it is certainly not easy for policy makers to find an appropriate "window of opportunity" for discretionary policy actions, as these have to be taken early enough to avoid the emergence of serious problems of persistence of either unemployment or of inflationary expectations, but late enough to make the policy authorities confident that a major macroeconomic disturbance has, in fact, occurred.

Today's sophisticated structure (relative to earlier configurations) of macroeconomic theory is obviously a result of contributions from many strands of economic analysis. Keynes and his followers, traditional as well as new, have supplied important missing pieces to the macroeconomic puzzle. It is time, however, to put Keynes to rest in the economists' Hall of Fame, where he certainly belongs, and to proceed with integrating the most relevant contributions by Keynes and his early and late followers with other strands of macroeconomic theory. Indeed, such integration is already on the way, as new classical theories and real business cycle models have recently started to incorporate sluggish prices, imperfect competition, imperfect information and persistence phenomena, at the same time as new Keynesians usually seem to accept some notion of equilibrium unemployment, the usefulness of rational expectations as a benchmark for analysis, and concern for the credibility of economic policies. Traditional labels on macroeconomic theories -- Keynesianism, new classical macroeconomics, real business cycle theories and new Keynesianism -- will, therefore, probably become increasingly irrelevant.

Institute for International Economic Studies, University of Stockholm; and IUI, Stockholm. 


\section{References}

Ball, L. and Romer, D. (1990). 'Real rigidities and the nonneutrality of money'. Review of Economic Studies, vol. 57 (April), pp. 183-203.

Barro, R. J. and Grossman, H. I. (1971). 'A general disequilibrium model of income and employment'. American Economic Review, vol. 61, pp. 82-93.

Basu, S. (1995). 'Intermediate goods and business cycles: implications of productivity and welfare'. American Economic Review, vol. 85, pp. 512-530.

Bernanke, B.S. and Gertler, M. (1995). 'Inside the black box: the credit channel of monetary policy transmission'. Journal of Economic Perspectives, vol. pp. 2748.

Blanchard, O.J. (1983). 'Price asynchronization and price-level inertia'. In R. Dornbusch and M.H. Simonsen (1983), Inflation, Debt, and Indexation. Cambridge MA: MIT Press.

Blinder, A.S. (1994). 'On sticky prices: academic theories meet the real world'. In N. G. Mankiw (ed.), Monetary Policy. Chicago: University of Chicago Press.

Bryant, J. (1983). 'A simple rational-expectations keynes-type model'. Quarterly Journal of Economics, vol. 98 (August), pp. 525-528.

Butters, J. K. and Lintner, J. (1945). Effects of Federal Taxes on Growing Enterprises, Boston: Harvard University, Graduate School of Business Administration.

Caplin, A. S. and Spulber, D.F.(1987). 'Menu costs and the neutrality of money'. Quarterly Journal of Economics, vol. 102, (November), pp. 703-725.

Carlton, D. W. (1986). 'The rigidity of prices'. American Economic Review, vol. 76 (September), pp. 637-658.

Chari, V.V., Kehoe, J. J. and McGrattan, E.R. (1996).'Sticky price models of the business cycle: can the contract multiplier solve the persistence problem?'. Federal Reserve Bank of Minneapolis, Research Department Staff Report 217.

Cooper, R. and John, A. (1988). 'Coordinating, coordination failures in Keynesian models'. Quarterly Journal of Economics vol. 103 (August), pp. 441-463.

Committee on the Working of the Monetary System (1959). Her Majesty's Stationary Office, London (Radcliff Report). 
Diamond, P. (1982). 'Aggregate demand management in search equilibrium'. Journal of Political Economy, vol. 90 (October), pp. 881-894.

Haberler, G. (1941). Prosperity and Depression. Geneva: League of Nations.

Hall, R. E. (1986). 'Market structure and macroeconomic fluctuations'. Brookings Papers on Economic Activity, no. 2, pp. 285-322.

Hart, O. (1982). 'A model of imperfect competition with Keynesian features'. Quarterly Journal of Economics, vol. 97 (February), pp. 109-138.

Henderson, J. M. and Quandt, R. (1971). Microeconomic Theory. New York: McGrawHill.

Kimball, M. S. (1996), "The quantitative analytics of the basic neomonetarist model". Journal of Money, Credit, and Banking, vol. 27, no. 4 (November), Part 2, pp. 1241-1277.

Layard, R. and Nickell, S. (1986). 'Unemployment in Britain'. Economica, vol. 53, no. 5, pp. 121-169.

Lindbeck, A. (1962). The 'New' Theory of Credit Control in the United States. 2nd ed., Stockholm Economic Studies, Pamphlet Series no. 1. Stockholm: Almqvist \& Wiksell.

---- (1963). A Study in Monetary Analysis. Stockholm Economic Studies, New Series no. 3. Stockholm: Almqvist \& Wiksell.

-..-- (1993). Unemployment and Macroeconomics. Cambridge, MA.: MIT Press.

Lindbeck, A. and Snower, D. (1992). 'Price inertia and production lags'. Seminar Paper No. 494, Institute for International Economic Studies.

Malinvaud, E. (1984). Mass Unemployment. Oxford: Basil Blackwell.

Mankiw, G., and Romer, D. (1991). 'Introduction'. New Keynesian Economics, Volume I, Cambridge MA: MIT Press.

Meyer, J. R. and Kuh, E. (1957). The Investment Decision, Cambridge Mass.: Harvard University Press.

Mas-Colell, A., Whinston, M.D. and Green J.R.(1995). Microeconomic Theory. Oxford: Oxford University Press.

Rosa, R. (1951). 'Interest rates and the central bank'. In Money, Trade and Economic Activity, Essays in Honor of J. H. Williams, New York: Macmillan. 
Rotemberg, J. (1987). 'The new Keynesian microfoundations', NBER, Macroeconomic Annual, pp. 69-104.

Shapiro, C. and Stiglitz, J. (1984). 'Equilibrium unemployment as a worker disciplinary device'. American Economic Review, vol. 74, no. 3, pp. 433-444.

Shleifer, A.(1986). 'Implementation cycles'. Journal of Political Economy, vol. 94, no. 6 , pp. 1163-1190.

Stiglitz, J. (1979). 'Equilibrium in product markets with imperfect information'. American Economic Review, vol. 69, pp. 339-345.

----- (1984). 'Price rigidities and market structure'. American Economic Review, vol. 74, pp. 350-355.

---- (1992). 'Capital markets and economic fluctuations in capitalist economies'. European Economic Review, vol. 36, pp. 269-306.

Stiglitz, J. E. and Weiss, A. (1981). 'Credit rationing in markets with imperfect information'. American Economic Review, vol. 71 (June), pp. 393-410.

Tobin, J. (1993). 'Price flexibility and output stability: an old keynesian view'. Journal of Economic Perspectives, vol. 7, no. 1, pp. 45-65.

Woodford, M. (1986). 'Stationary sunspot equilibria in a finance constrained economy'. Journal of Economic Theory, vol. 40, pp. 128-137. 